\title{
empleo de cenizas puzolánicas para la preparación de hormigón en masa para presas
}

(Barrage construit avec emploi de cendres pouzzolaniques)

EDITORIAL

De: «Journal de la Construction de la Suisse Romande», año 32 , núm. 1, enero 1957, pág. 3y

En la construcción de la presa Liberty Dam, destinada al abastecimlento de agua de Baltimore, se han utilizado $8.300 \mathrm{t}$ de cenizas. La proporción que se ha empleado es de $40 \mathrm{~kg}$ de cenizas para tres sacos de cemento. Ha sido ésta la primera vez en que se ha utilizado tal sistema; la masa de hormigón preparada ha sido de $125.000 \mathrm{~m}^{2}$, habiéndose conseguido una economía de 1.500 .000 dólares, aunque las cenizas procedían de una central térmlca situada a $35 \mathrm{~km}$.

En esta construcción se han podido comprobar todas las ventajas habituales de las puzolanas: temperatura de hidratación baja; segregación reducida; gran resistencia final.

La composición de las cenizas puzolánicas utilizadas era la siguiente: SiO, 40 por 100 (mínimo); $\mathrm{Al}_{2} \mathrm{O}_{3}, 15$ por 100 (mínimo); $\mathrm{C}, 10$ por 100 (máximo); humedad, 3 por 100 (máximo).

Se empleó, también, un agente aireante.

S. F.S. 